\title{
Mapping the Nepali NGO Sector: Understanding the evolutionary patterns
}

By K C, Dipendra and Lorsuwannarat, Tippawan

Mr. KC is Ph.D. Candidate, Graduate School of Public Administration, National Institute of Development Administration, Bangkok, Thailand Contact: kc.dipendra@gmail.com and Prof. Lorsuwannarat is Professor of Public Administration, Graduate School of Public Administration, National Institute of Development Administration, Bangkok, Thailand

\section{Abstract}

The number of Nepali NGOS is on the rise. However, except the total number of NGOs, the information about the spatial distribution of these NGOs is rarely available. This descriptive paper utilizes the data from the Social Welfare Council and Aid Management Platform of the Ministry of Finance to explore the spatial distribution of NGOs and foreign aid in Nepal. It uses descriptive statistics and visual graphs and charts to demonstrate the distribution. The study finds that NGOs and foreign aid are agglomerated in province number three of Nepal. The paper suggests that the uneven distribution of $N G O s$ and aid leads to uneven realization of development outcomes in Nepal. Registration, renewal, and procedures are extremely lengthy and tedious in Nepal.

\section{Keywords:}

Foreign Aid, Nepal, NGO, Spatial Distribution,

\section{Introduction}

The size and scope of the Nepali NGO sector is a contested issue. The number of NGOs from Social Welfare Council is often used to denote the size of the sector. Except the total number of NGOs, further details of the organizations, evolutionary pattern, spatial distribution of these organizations is largely missing. This paper aims to unbox the historical evolutionary pattern of the growth of the sector in Nepal. Furthermore, this descriptive article also provides a broader context of the environment in which Nepali NGOs operate.

Descriptive studies like this carry paramount importance. However, they do not get much space and attention in the scholarly journals citing that the description alone does not contribute significantly to the field of study. Yet, the author argues that such studies are the foundation for 
other studies. Descriptive studies based on secondary sources from developing countries are of even greater importance partly because the accessibility and availability of data is very rare, even if the data is available, no systematic trustable analysis is found. In the context of Nepali NGOs, availability of data remains as a major challenge. This descriptive study is meritorious on its own because it uncovers the scope and breadth of Nepali NGO and aid industry. It will provide a comprehensive view of the growth of the sector and other antecedents.

This paper starts by outlining the methodology adopted for the paper, followed by the economic, social and human development context of the country compared to its neighbors. Third, it presents a brief history of Nepali NGOs, followed by the flow of foreign aid in Nepal. It the presents the socio-political changes their effect on the founding rate of NGOs.

\section{Methodology}

Given the exploratory nature of the study, this paper relies on the secondary sources of data. Different national and international sources of data is used. Only descriptive statistics like mean and line and bar charts are used in this article. Stata: Software for Statistics and Data Science version 13.1 was used to compile and aggregate all the data. Visual graphics like Charts and maps were generated using Tableau version 2019.1, GeoDa, and Microsoft Excel Office 365.

The author filed an official application (registration number 4610) requesting the database of NGOs affiliated with Social Welfare Council (SWC) of Nepal on December 25, 2018. Social Welfare council is the government unit under the ministry of Social Welfare that is responsible to coordinate the activities of all the social organizations in Nepal. NGOs must take the affiliation and approval from the institution to receive any foreign donation or grant. Furthermore, the approval letter from SWC is needed for the renewal of the NGO. Hence, the dataset from the SWC is the most comprehensive data that is available in Nepal. NGOs in Nepal seems only fund consuming associations of development (Badal, 2016).

The database contains the name of the NGO, working sector, name of the founder, address, and the date the organization was affiliated with SWC. 153 NGOs were removed from the analysis because they lack SWC affiliation date and geographical information. Hence, only 49,077 organizations were considered for the analysis.

While the dataset from Social Welfare Council is quite comprehensive, there are indications that the data is prone to some problems. First, the database lists the self-reported location of the organization at the time of registration. The organization's registered site may be different than 
its operational place. Second, once registered, the entry is not updated. Hence, it is likely that location change during the lifecycle of the organization is not recorded. Given the exploratory nature of the study, this paper uses the data source acknowledging the limitation it has.

Furthermore, the data for multilateral, bilateral and INGO funding comes from the Aid Management Platform (AMP). The AMP is a web-based aid information system which records both on-budget and off-budget data reported online by International Economic Cooperation Coordination Division (IECCD) of Ministry of Finance and the development partners (DPs) as well as INGOs (IECCD, 2012, 2013, 2014, 2015, 2016, 2017, 2018).

\section{Measurement of Aid Allocation}

The empirical analyses measure aid per district in two ways. The first measure is the natural $\log$ of the total dollar value per 10000 residents of each district's projects in the case of multilateral and bilateral aid, and INGO aid (Briggs, 2018). The dollar value of multilateral and bilateral aid per 10000 residents is the average of aid disbursed between 2011 to 2017. The dollar value of INGO aid per 10000 residents is the average of INGO aid disbursed between 2013-2017.

This study distributes the amount for each project by dividing the overall amount of projects by the number of districts in which project locations can be found to measure the aid through NGOs. The dollar value of NGO aid per 10000 residents is the actual amount channeled through NGOs in the FY 2014.

\section{Results and Discussion}

\section{Economic Context}

Nepal is currently going through post-conflict institutional reform stage. Following the twelve years long armed conflict and subsequent failed attempts to draft a new constitution, Nepal finally has a new constitution. The new constitution of the country makes it a Federal Republic of Nepal. The first election was conducted earlier last year based on the new constitution. Nepal had its first election at the local level after two decades in 2018. Country is currently practicing the newly formulated federal structure, which has three tiers of government; a central, a provincial, and the local government. 
Table 1 GDP Per Capita (Current USD) Compared to other South Asian Countries

\begin{tabular}{|l|l|l|l|l|}
\hline Country & 1990 & 2000 & 2010 & 2017 \\
\hline Maldives & 964 & 2,227 & 7,100 & 11,151 \\
\hline Sri Lanka & 464 & 869 & 2,808 & 4,074 \\
\hline Bhutan & 558 & 766 & 2,179 & 3,130 \\
\hline India & 364 & 439 & 1,346 & 1,942 \\
\hline Pakistan & 372 & 534 & 1,040 & 1,548 \\
\hline Bangladesh & 298 & 406 & 758 & 1,517 \\
\hline Nepal & 193 & 231 & 592 & 849 \\
\hline Afghanistan & & & 551 & 550 \\
\hline
\end{tabular}

Source: World Development Indicators, (The World Bank, 2019)

Nepal has one of the lowest GDP per capita compared to other South Asian nations. The GDP per capital was USD 849 in 2017, only above Afghanistan. Nepal's GDP growth rate declined during the conflict. However, recent figures suggest that Nepal has growth trajectory of its annual GDP growth rate. In 2017, Nepal's GDP growth rate was the highest in South Asia (See Table 2 for a comparison of other South Asian Countries).

Table 2 Annual GDP Per Capita Growth Rate in South Asia

\begin{tabular}{|l|l|l|l|l|}
\hline Country Name & 1990 & 2000 & 2010 & 2017 \\
\hline Afghanistan & & & 11.19 & 0.14 \\
\hline Bangladesh & 3.05 & 3.25 & 4.4 & 6.16 \\
\hline Bhutan & 9.43 & 3.97 & 9.71 & 3.35 \\
\hline India & 3.37 & 2.02 & 8.76 & 5.49 \\
\hline Maldives & & 1.66 & 4.32 & 4.81 \\
\hline Nepal & 2.09 & 4.25 & 3.72 & 6.72 \\
\hline Pakistan & 1.46 & 1.91 & -0.48 & 3.66 \\
\hline Sri Lanka & 5.06 & 5.36 & 7.36 & 2.15 \\
\hline
\end{tabular}

Source: World Development Indicators, (The World Bank, 2019)

\section{Social and Human Development}

Compared to other South Asian nations, Nepal has 15 percentages of its population under the 
absolute poverty (headcount measure). However, absolute poverty has declined substantially in Nepal compared to other South Asian nations over the last 17 years. Compared to 46.1 percentage of people living under the poverty, today the number has declined by two folds (The World Bank, 2019). In terms of Human Development Index, Nepal has an HDI of 0.574 and ranks $149^{\text {th }}$ in the world in terms of human development. Nepal made some significant progress in achieving some of the millennium development goals. For example, it reduced the infant mortality rate per 1,000 live births to 28 compared to 60 in 2000 (UNDP, 2018).

Table 3 Poverty headcount ratio in South Asia

\begin{tabular}{|l|l|l|l|l|}
\hline Country & 1990 & 2000 & 2010 & 2017 \\
\hline India & 45.9 & 38.2 & 31.1 & 21.2 \\
\hline Nepal & 61.9 & 46.1 & 15 & 15 \\
\hline Bangladesh & 44.2 & 25.7 & 19.6 & 14.8 \\
\hline Pakistan & 58.9 & 28.6 & 8.3 & 4 \\
\hline Bhutan & & 17.6 & 2.2 & 1.5 \\
\hline Sri Lanka & 8.7 & 3.8 & 2.4 & 0.7 \\
\hline Afghanistan & & & & \\
\hline Maldives & & & 7.3 & \\
\hline
\end{tabular}

Source: World Development Indicators, (The World Bank, 2019)

While poverty in general has declined in the country, the spatial distribution of poverty is not same across the country. Western region of Nepal and some selected districts of the southern plains have relatively higher number of people living under the absolute poverty (See Figure 1). 
Figure 1 Quantile map of spatial distribution of percentage of population under poverty line.
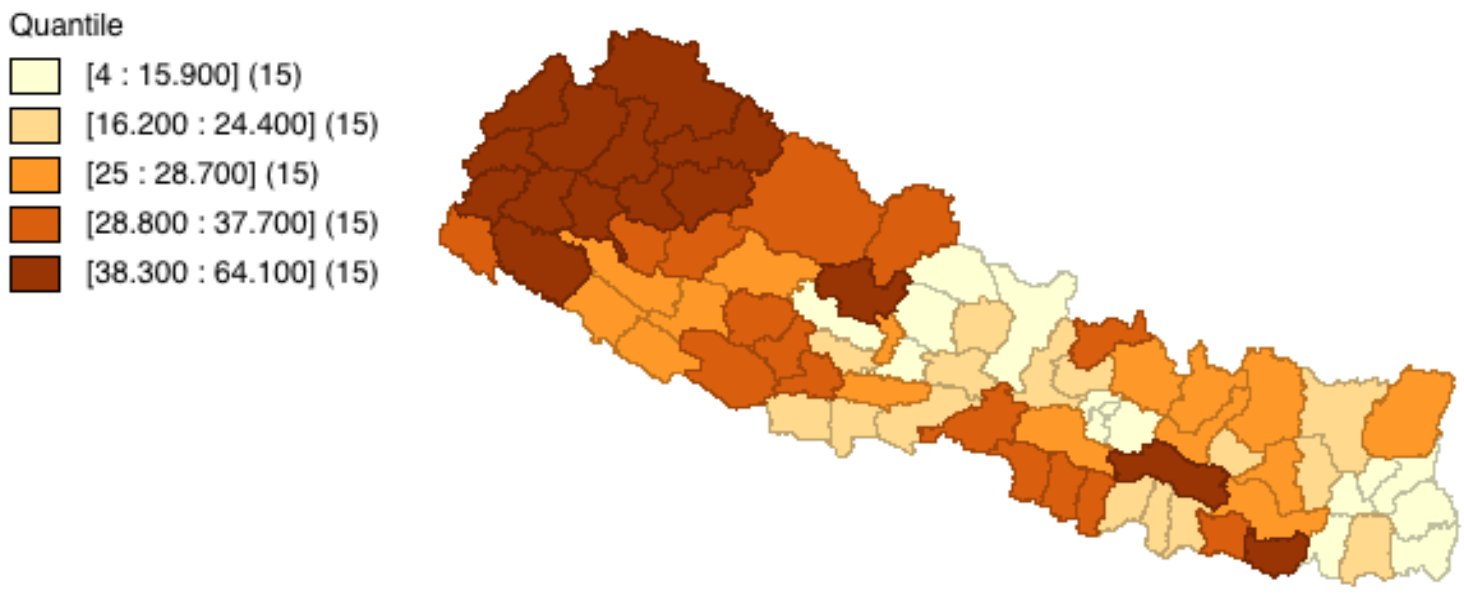

Map Source: $(K C, 2018)$

\section{An abridged history of Nepali NGOs}

Today, Nepal is home to some 29 million people and a little over 49,000 officially registered NGOs (Social Welfare Council, 2018). Some unofficial sources claim that the number of NGOs in Nepal may be a little over 83,000 (ICNL, 2017). While more conservative number suggest the number to be somewhat around 6000 (NGO Federation of Nepal, 2019). There is no one credible centralized record of the total number of NGOs in the country. Despite the confusion over the exact number of NGOs, NGOs are well established institutions in the Nepalese society.

This paper bases its analysis on the database of Social Welfare Council of Nepal. Hence, the numbers used past this section should be understood as the data from the Social Welfare Council until and unless stated otherwise.

\section{NGOs as actors in National Development Policies}

Nepal started its planned development efforts since 1956. Since then, country has seen fifteen periodic development plans. NGOs were included as key partners of development since the eighth (1992-1997) periodic plan. The emphasis of the eighth plan was to alleviate the poverty in the country and NGOs were considered as the partners in the developmental efforts of the country. Interim government of Nepal also introduced a 13-point policy on NGOs where government agencies were encouraged to coordinate with NGOs in rendering their services to citizens as well as encouraged to facilitate resources for NGOs (NPC, 1992). Furthermore, the eighth 
plan also clearly outlined its directive for INGOs and NGOs to make them operate in rural and underserved communities. In the meantime, INGOs were encouraged to partner with the local NGOs to execute their programs.

The national periodic plans, since the eighth plan have seen NGOs as crucial actors of development in Nepal. Country is now on the verge of implementing its fifteenth plan and NGO sector remains as one of the four major sectors along with the public, private, and co-operative sectors contributing to the development of the country (NPC, 2019, p. 52).

Figure 2 depicts the growth trajectory of NGOs in Nepal. It took twenty-four years to have the first three hundred fourteen NGOs while the remaining NGOs were established within a matter of the last twenty-eight years. NGOs in Nepal are clearly the post- democracy phenomenon in Nepal. There was an explosion in the number of NGOs after the demise of totalitarian Panchyat regime of the country.

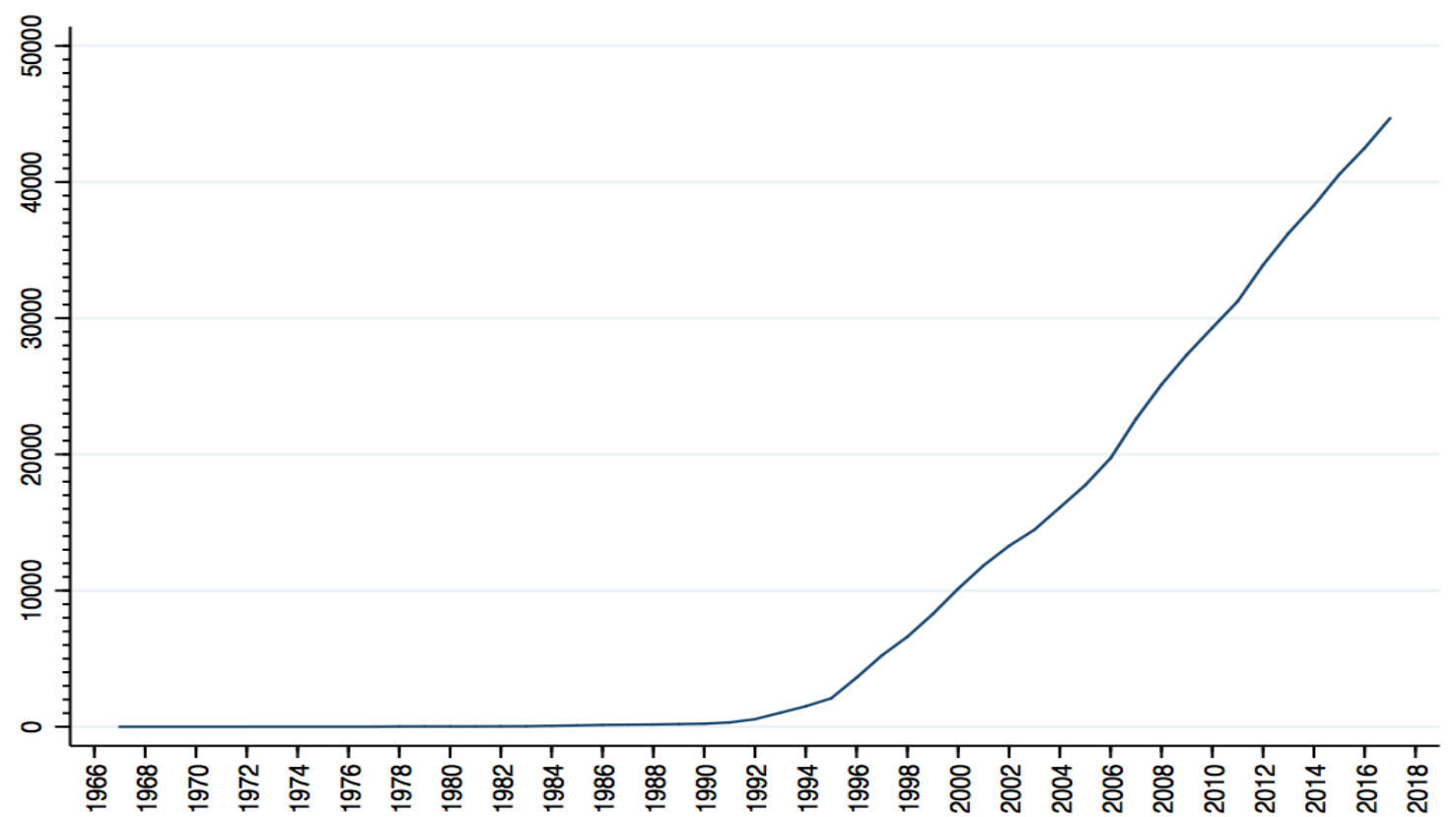

Figure 2 Growth rate of total number of NGOs in Nepal

If we look at the spatial distribution of NGOs per 10,000 residents in Nepal (Figure 3), clearly the concentration of these organizations is in the capital city and its vicinity. Northern regions of Western Nepal and the vicinity of the capital has the highest density of NGOs in Nepal. Figure 3 Quantile map of spatial distribution of NGOs per 10,000 residents in Nepal 

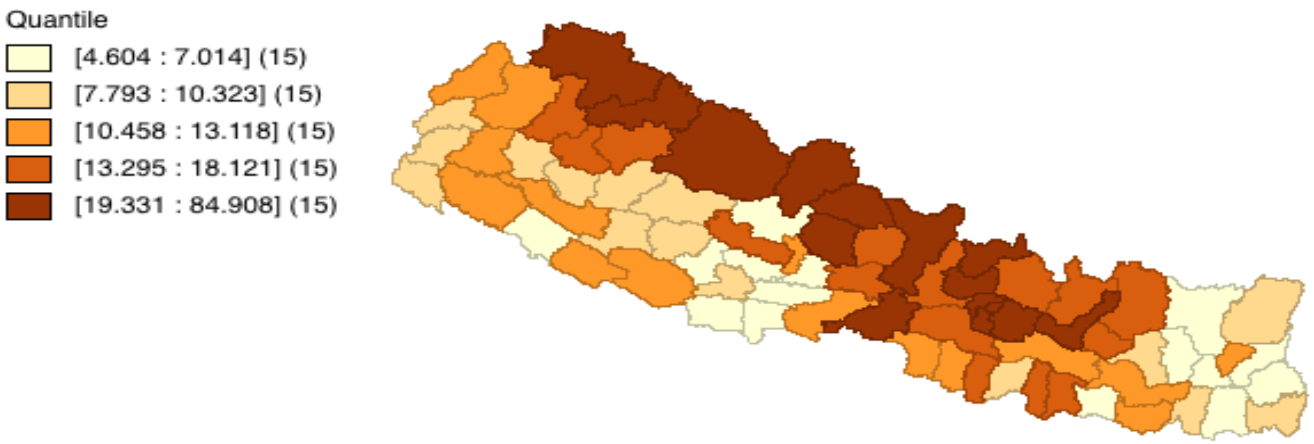

Map Source: (K C, 2018)

Figure 4 portrays the sectoral distribution of NGOs in Nepal. More than sixty-four percentage of the registered NGOs indicated that they were working for the community and rural development. Twelve percentage of the organizations reported youth services as their preferred sector of work. Seven percentage of NGOs reported as working in providing services to women or representing their rights. Four percentage of organizations registered to work on the moral development. These numbers were followed by three percentage of organizations working in environment protection. Other sectors like child welfare, health services, disability, education, and HIV \& AIDS control had less than two percentage of registered NGOs. Figure 4 Functional distribution of NGOs in Nepal

Source: $(K C, 2018)$

Furthermore, most of the NGOs affiliated with Social Welfare Council are based in province three followed by province two, province one, four, five, seven, and six respectively.

Figure 5 Province wise distribution of NGOs

Source: $(K C, 2018)$

\section{Flow of Foreign Aid in Nepal}

Nepal has steadily received foreign aid from different OECD countries. Net ODA received is in 
the surge after the end of the armed conflict in Nepal. Source: World Development Indicators, (The World Bank, 2019)

Figure 6 presents the trend of ODA Nepal received since 1960. Nepal received USD 16 as foreign aid per capita at the beginning of this century and it receives USD 45.55 per capita (The World Bank, 2019).

Table 4 Net ODA received per capita (current US\$) compared with other South Asian countries.

\begin{tabular}{|l|l|l|l|l|}
\hline Country Name & 1990 & 2000 & 2010 & 2017 \\
\hline Bhutan & 86.66 & 90.34 & 191.65 & 158.99 \\
\hline Afghanistan & 9.81 & 6.55 & 221.70 & 104.80 \\
\hline Maldives & 93.48 & 68.54 & 305.30 & 84.39 \\
\hline Nepal & 22.37 & 16.14 & 30.15 & 45.55 \\
\hline Bangladesh & 20.28 & 9.20 & 9.52 & 23.42 \\
\hline Sri Lanka & 42.04 & 14.83 & 28.61 & 13.85 \\
\hline Pakistan & 10.47 & 4.96 & 16.84 & 10.98 \\
\hline India & 1.60 & 1.31 & 2.29 & 2.31 \\
\hline
\end{tabular}

Source: World Development Indicators, (The World Bank, 2019)

Figure 6 Annual net ODA received

Source: World Development Indicators, (The World Bank, 2019)

As shown by Figure 7, in an average between 2011-2017, foreign aid has contributed roughly around six percentage to the total GDP of the country. The contribution has remained between five to eight percentage of the GDP since the beginning of this decade. 
Figure 7 Volume of foreign Aid and Contribution to GDP

Source: Aid Management Platform, 2018

\section{Subnational Flow of Aid}

As portrayed by Figure 8, Source: $(K C, 2018)$

Figure 9,and Figure 10, there is significant variation in the aid allocation across different parts of the country by different types of aid. However, Kathmandu valley has received significantly higher amount of aid compared to other parts of the country. The average foreign aid flow in the Kathmandu valley is almost seven times higher compared to the average aid flow outside the Kathmandu valley between 2010 to 2017. An average of USD 669,534 was allocated inside Kathmandu valley while only USD 95,687 outside the Kathmandu valley (Ministry of Finance, 2012, 2016, 2017a). For a comprehensive review of aid allocation patterns by different donors, see K C (2018).

Figure 8 Subnational allocation of multilateral and bilateral aid (2011-2017)
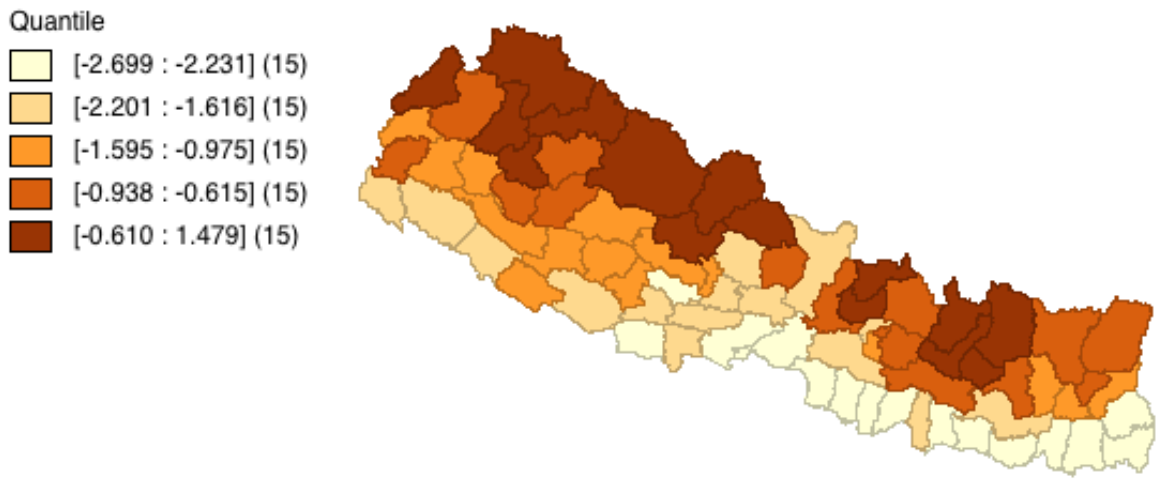
Source: $(K C, 2018)$

Figure 9 Subnational allocation of INGO aid (2013-2017)
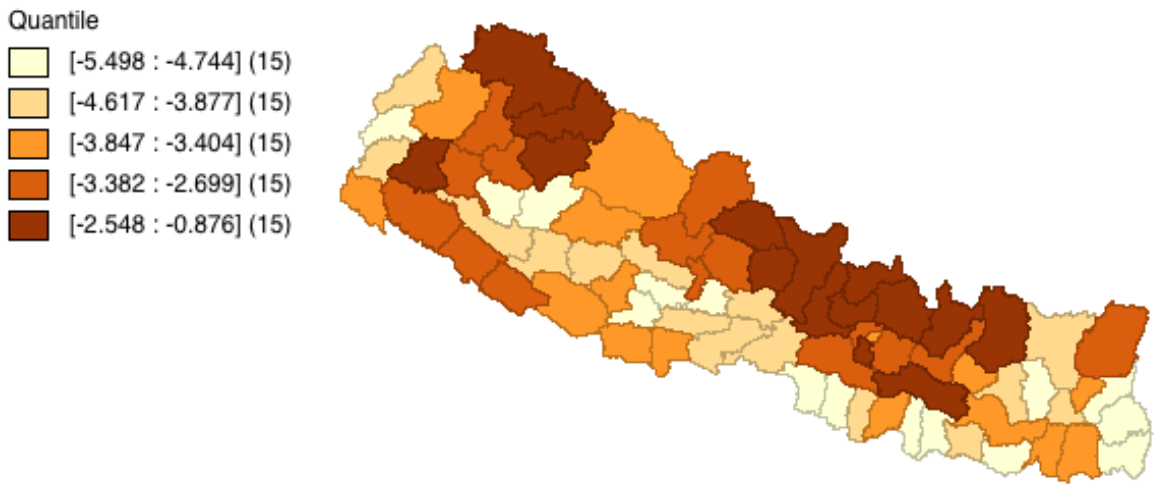

Source: $($ K C, 2018)
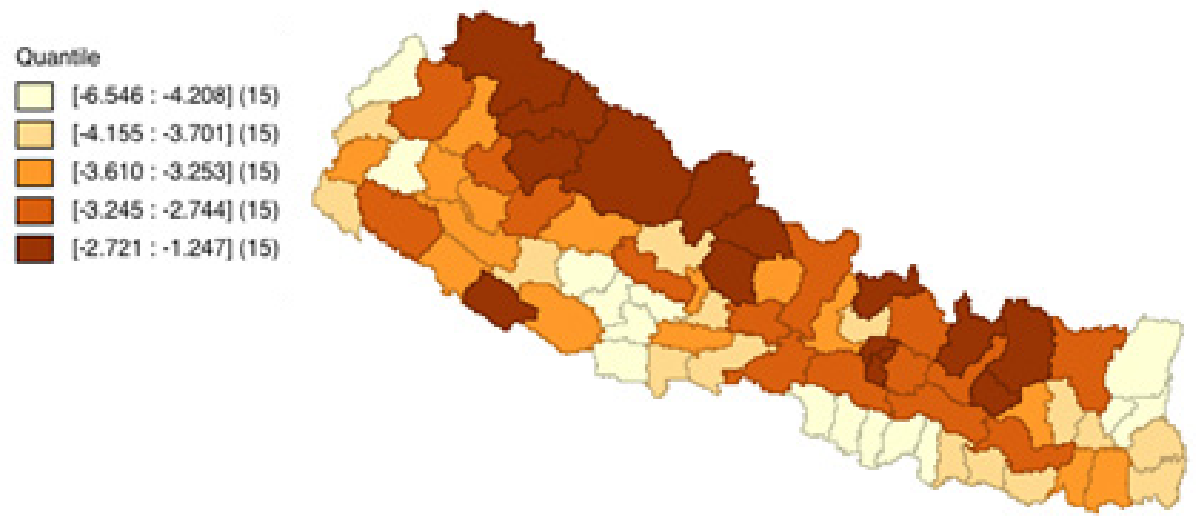

Figure 10 Subnational allocation of NGO aid (2014)

Source: $(K C, 2018)$

In Figure 11, left Axis shows the per capita ODA disbursement to seven provinces of Nepal. Right axis shows the Human Development Index of Each province. As depicted by the figure, there is uneven distribution of aid in the provinces. Province three has $0.51 \mathrm{HDI}$ indicating a relatively better condition of human development compared to province seven, which has an HDI of 0.42 . However, province three received almost three times higher aid per capita of USD 64 during 2011-2017 compared to province seven that received only USD 24 (Ministry of Finance, 
2012, 2013, 2014, 2015, 2016, 2017b, 2018).

Figure 11 Per Capita ODA Disbursement and HDI by province

\section{Per Capita Disbursement and HDI by province}

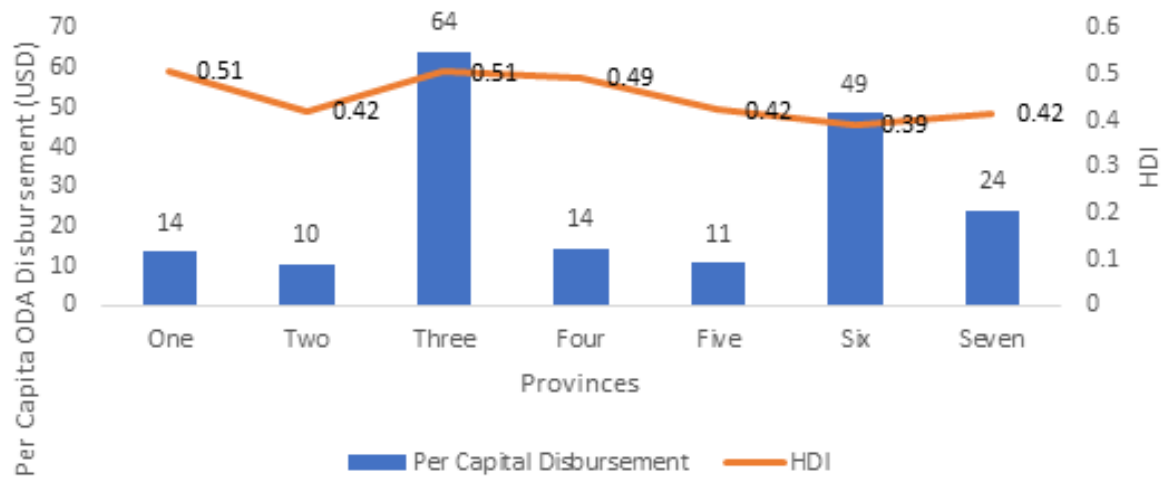

Source: Aid

Management Platform, 2018, Author generated chart

\section{Socio-Political Changes and NGOs}

Figure 12 highlights major political changes and the Annual NGO entry rate of Nepali NGOs. Number of Nepali NGOs picked up with the restoration of multi-party democracy in Nepal. Entry rate of NGOs seems to shoot up at major political events in the country. Every major political change in the country seems to have affected the NGO entry rate. At the national level, the NGO registration can be divided distinctly in two waves. The first wave of Nepali NGO registration started in 1990 and continued upwards until the beginning of this century. The second big wave of NGO birth started in 2002 when the armed conflict was escalating with fragile domestic politics. The upward trend in annual registration continued in the following years. 2006 saw the peak of NGO registration in the country. This was the time when armed conflict ended, power of monarchs was curbed significantly.

The bird's eye view of the registration trend and political changes clearly demonstrates that NGOs see the moments of political turmoil as an opportunity for them. Political turmoil often leaves deep scars in the society. Ruling elites often forget the pain and need of citizens and focus on securing their power. While they do this, citizens are often deprived of basic services. As a result, this creates an opportunity for NGOs to act as the legitimate actors in fulfilling these needs.

Figure 12 Major Political Changes and Annual NGO Entry Rate 1967 - 2018 


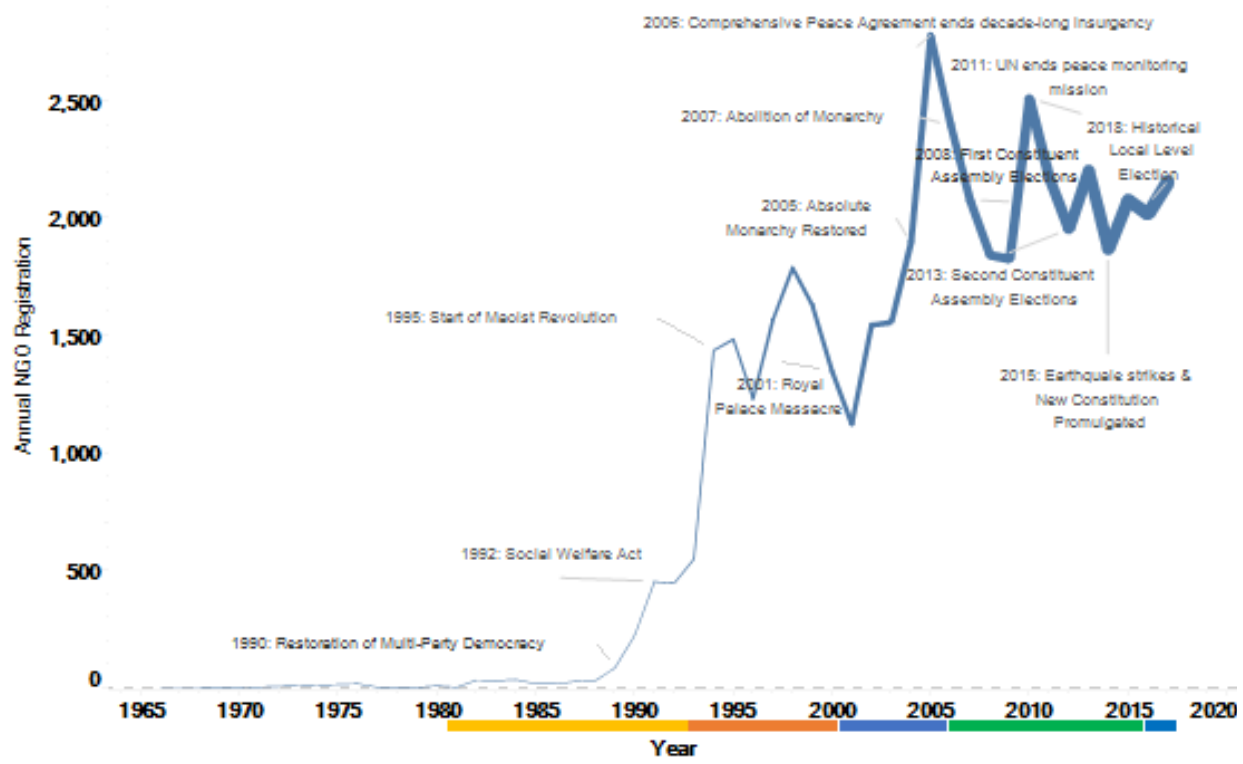

Source: $(K C, 2018)$

Thickness of the line in Figure 12 represents the overall density of NGOs and the color in X-axis represents the timeframe of political developments in Nepal

\section{National Laws and Regulations Affecting Sector}

\section{Constitutional Framework}

Nepal's constitution recognizes different individual freedoms and civil rights. The constitution guarantees considerably freedom and rights to its citizens. For instance, articles 16, - 20, and 43 relate to various individual freedoms, including civil rights like right to life, dignity, equality and freedom, right to information, right to justice, right to social security, etc. The constitution also further safeguards the political rights like rights to association, expression, and exchange of ideas, participation in the state system, etc. Furthermore, articles $(17,25,29,33,34)$ stipulate the economic rights of the citizens, articles $31,35,38,39,40$ guarantees right to education, health, rights of children, women, and so called 'Dalits". It also further guarantees religious freedom and safeguards its citizens' right to practice their own religion without affecting others.

The constitution of the country also sets an enabling environment for civil society by ensuring the freedom of opinion and expression, right to assemble peacefully without arms, to form unions and associations, and freedom of mobility within the country as well as the liberty to engage in a profession of their choice. These freedoms are stipulated in the third part of the constitution." 
The constitution particularly article 51 states that the government should promote and pursue social justice and principles of inclusion. It states that the government will adopt policies "involving NGOs and INGOs only in the areas of national needs and priority, by adopting a one-door policy for the establishment, endorsement, engagement, regulation and management of such organizations, and by making the investment and role of such organizations accountable and transparent."

\section{National Laws and Regulations Affecting Sector}

Nepal is going through huge legal reforms due to its new federal structure. These are the current legal instruments that guide the registration and operation of NGOs. However, the Nepali government is drafting a new Social Organization Act, 2075, an umbrella law which would regulate nearly every form of association. This law would replace Association Registration Act, 1977, National Directorate Act, 2018 and Social Welfare Act, 2049. This draft law is being reviewed and redrafted by multiple ministries. There are several issues in the bill that is under discussion.

First, the draft clearly envisions NGOs as service providers that would operate within a certain geographical area engaged in one type of activities. For instance, the draft law proposes organization to identify its work only in one category among thirteen functional categories of their work. It is practically impossible to demarcate the boundaries of the proposed functional categories. For instance, raising awareness is one category and the second category is the advocacy and promotion of rights. The proposed bill is geared towards discouraging NGOs to engage in more than one functional area with the provision of additional fees for those declaring more than one functional area of their work.

Second, the bill envisions a central registrar's office for the registration, operation and to regulate organizations that operate nationwide or have working area in more than two provinces, professional associations, INGOs, and NGOs that register in Nepal but want to operate internationally. This proposed body is somehow identical to existing Social Welfare Council. In the meantime, it also envisions provincial and local registrar's office for organizations operating province wide or more than two local levels. Furthermore, proposed bill is ambiguous in determining the standard process for the renewal process. It gives power to the local level in determining the requirements for the renewal of such organizations. While the idea of empowering the local level is encouraging, yet, having a clear standard nationwide for organization renewal would avoid confusion among organizations. 
The Association Registration Act, 1977: All the NGOs in Nepal are registered under the association registration act of 1977 . This act serves as the primary legal instrument that guides the registration and functioning of NGOs and other civil society organizations in the country. The act defines "association" as an "association, institution, club, circle, council, study center, etc. established for the purpose of developing and extending social, religious, literary, cultural, scientific, educational, intellectual, philosophical, physical, economical, vocational, and philanthropic activities. It also includes friendship associations."

The National Directorate Act, 1961: Professional associations and organizations that are involved in the development of their members as well as the broader members of the community are registered under this act. Professional associations like Nepal Bar Association, Nepal Press Council, Teachers Union of Nepal, Nepal Federation of Journalist Associations and the NGO Federation of Nepal are registered under this act. Associations are either formed by the government or need the approval from the cabinet meetings through the relevant line ministry or be established or envisioned in the law.

The Social Welfare Act, 1992: This act was introduced by the government to govern and coordinate the provision of "social welfare" activities and "social service" activities. Any CSO willing to receive the funding from the government or foreign entities must be affiliated with the Social Welfare Council established by the law and take prior approval to receive the funding.

The Company Act, 2006: Articles 166 and 167 of the company act provide the legal basis for registration of non-profit distributing companies. Registration requires at least five citizens coming together to promote any profession, business, intellectual, educational, social, charity, or welfare activities, with a non-profit intent. According to company registrar's database, since the promulgation of the law, a total of 1,782 entities have registered as the non-profit distributing companies. 


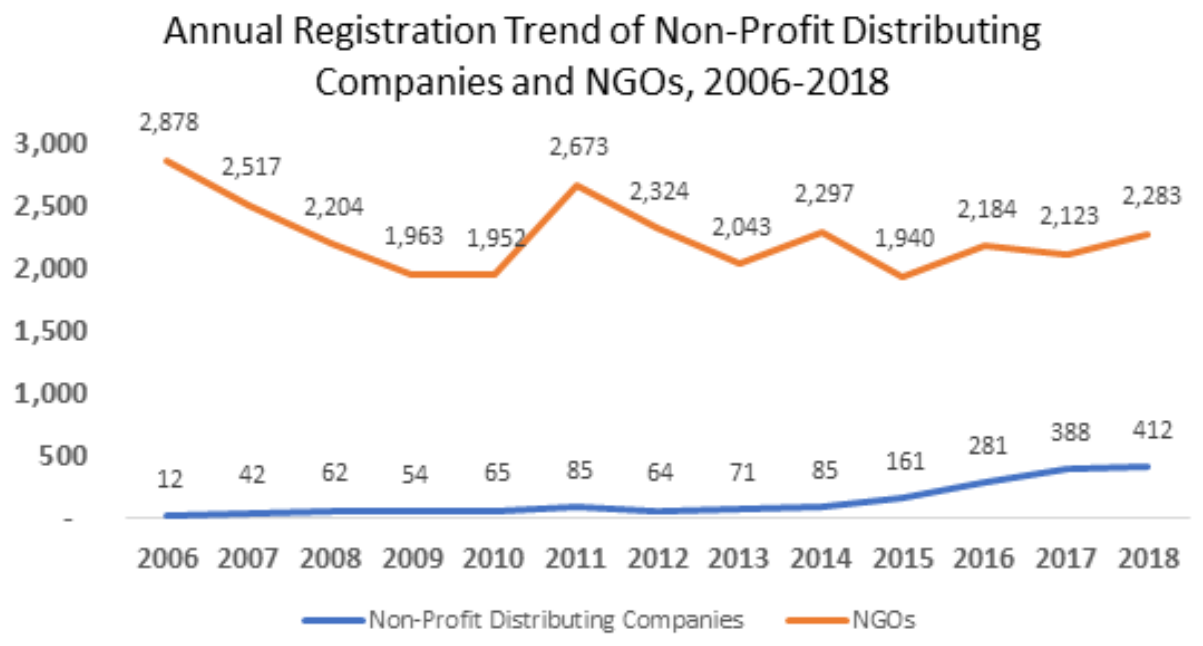

Data Source: Company Registrar's Office \& Social Welfare Council, 2018, Author generated chart.

Table 5 Summary of Laws and Policies Affecting NGOs

\begin{tabular}{|l|l|l|}
\hline Year & Law/Policies & Implication for NGO \\
\hline 1961 & National Directive Act & $\begin{array}{l}\text { First modern law governing registration of social } \\
\text { organizations. }\end{array}$ \\
\hline 1977 & $\begin{array}{l}\text { Association Registration } \\
\text { Act }\end{array}$ & It is the primary framework law for NGOs in Nepal \\
\hline 1992 & Social Welfare Act & $\begin{array}{l}\text { Governs the provision of "social welfare" activity and } \\
\text { "social service" activity. }\end{array}$ \\
\hline 2006 & The Company Act & Allows for the formation of not for profit companies. \\
\hline
\end{tabular}

Source: $(K C, 2018)$

\section{Conclusion}

This paper started with an aim of illustrating the evolutionary patterns of Nepali NGOs. The focus of the paper was to illustrate the pattern of the growth of the sector between 1967-2018. It presented the spatial distribution of NGOs as well as foreign aid in Nepal. In general, the descriptive analysis suggests that NGOs and foreign aid is concentrated in province number three. Furthermore, the paper also finds that the trend of registering non-profit distributing companies is on the rise since 2006. The growing number of nonprofit distributing companies and NGOs 
suggest a very vibrant associational life in Nepal.

However, the agglomeration of such organizations in the capital city and province three alone is alarming. If the goal of such organizations is to help eradicate poverty, proper attention should be given to the placement of such organizations. The claim that NGOs and foreign aid help people in need will be futile if they do not establish themselves closer to the people who are in need.

\section{References}

Badal B. P., (2016). NGOs in Rural Development: A Critical Analysis, Janabhawana Research Journal Vol. 1 Issue 1, 8-15

Briggs, R. C. (2018). Leaving No One Behind? A New Test of Subnational Aid Targeting. Journal of International Development, 30(5), 904-910. doi:10.1002/jid.3357

ICNL. (2017). Civic Freedom Monitor: Nepal. Retrieved from http://www.icnl.org/research/ monitor/nepal.html\#analysis

K C, D. (2018). Which aid targets the poor at the sub-national level? Paper presented at the 11th ISTR Conference, Amsterdam.

Ministry of Finance. (2012). Development Cooperation Report FY 2010-2011. Retrieved from Kathmandu:

Ministry of Finance. (2013). Development Cooperation Report FY 2011-2012. Retrieved from Kathmandu:

Ministry of Finance. (2014). Development Cooperation Report FY 2012-2013. Retrieved from Kathmandu:

Ministry of Finance. (2015). Development Cooperation Report FY 2013-2014. Retrieved from Kathmandu:

Ministry of Finance. (2016). Development Cooperation Report FY 2014-2015. Retrieved from Kathmandu:

Ministry of Finance. (2017a). Development Cooperation Report. Retrieved from Kathmandu:

Ministry of Finance. (2017b). Development Cooperation Report FY 2015-2016. Retrieved from Kathmandu, Nepal: 
Ministry of Finance. (2018). Development Cooperation Report FY 2016-2017. Retrieved from Kathmandu:

NGO Federation of Nepal. (2019). NGO Database Portal. Retrieved from http://database. ngofederation.org/

NPC. (1992). The Eighth Five-Year Plan (1992-97). Kathmandu: Government of Nepal

NPC. (2019). 15th Plan Approach Paper. Kathmandu: Government of Nepal

Social Welfare Council. (2018). List of NGOs Affiliated with Social Welfare Council. Retrieved from Kathmandu: http://www_swc.org.np/wp-content/uploads/2017/08/ngo_rec.pdf

The World Bank. (2019). World Development Indicator.

UNDP. (2018). Human Development Indices and Indicators. Retrieved from http://hdr.undp. org/en/content/human-development-indices-indicators-2018-statistical-update 